\title{
MENINGKATKAN MOTIVASI BELAJAR BAHASA ARAB PADA SISWA SEKOLAH \\ MENENGAH ATAS MELALUI PELATIHAN GOAL SETTING
}

\section{IMPROVING MOTIVATION TO LEARN ARABIC IN THE HIGH SCHOOL STUDENT WITH GOAL SETTING TRAINING}

\author{
Muhammad Erwan Syah \\ Hepi Wahyuningsih \\ Ratna Syifa'a Rachmahana \\ Fakultas Psikologi dan Ilmu Sosial Budaya Universitas Islam Indonesia Yogyakarta \\ E-mail: muhammaderwansyach@yahoo.com
}

\begin{abstract}
This study aims to determine the effect of goal setting training on students' motivation to learn Arabic. Participants were 26 students of class XI of SMA "X" Yogyakarta. They were grouping into 13 students as the experimental group and 13 students as a control group with pre-post control group design. Data were collected with Arabic learning motivation scale, interviews and observations. Result showed that both pretest-posttest ( $Z=-4359, P=0.000, P<0.05)$ and pretest-follow up score on motivation to learn Arabic improve after treatment $(Z=-2500, P=0.012, P<0.05)$. Therefore goal setting training could enhance Arabic learning motivation.
\end{abstract}

Keywords: Goal Setting Training, Arabic Learning Motivation, High School Student

\section{ABSTRAK}

Penelitian ini bertujuan untuk mengetahui pengaruh pelatihan goal setting pada motivasi belajar bahasa Arab siswa. Subjek dalam penelitian ini adalah 26 siswa kelas XI SMA "X" Yogyakarta, yang dibagi menjadi 13 siswa sebagai kelompok eksperimen dan 13 siswa sebagai kelompok kontrol. Pengumpulan data dilakukan dengan menggunakan skala motivasi belajar bahasa Arab, wawancara dan observasi. Rancangan penelitian yang digunakan adalah pre post control group design. Hasil analisis data menunjukkan adanya peningkatan skor motivasi belajar bahasa Arab, baik pada skor prates-pascates $(Z=-4.359, P=0.000, P<$ 0.05) maupun tindak lanjut $(\mathrm{Z}=-2.500, \mathrm{P}=0.012, \mathrm{P}<0.05)$. Dengan demikian dapat dikatakan bahwa pelatihan goal setting mampu meningkatkan motivasi belajar bahasa Arab siswa kelas XI SMA " $X$ " Yogyakarta.

Kata Kunci : Pelatihan Goal Setting, Motivasi Belajar, Sekolah Menengah Atas

Bahasa Arab merupakan salah satu bahasa internasional. Di Indonesia, bahasa Arab merupakan salah satu bahasa asing yang diajarkan di sejumlah Sekolah
Menengah Atas (SMA). Menurut catatan PBB pada tahun 2014, bahasa Arab menempati urutan ke-2 bahasa internasional setelah bahasa Inggris. Seiring 
pesatnya persaingan global yang ada dan mayoritas di negara Indonesia penduduknya beragama Islam, maka tuntutan akan penguasaan bahasa Arab pun semakin besar pula (Syah, 2010). Oleh sebab itu, siswa Sekolah Menengah Atas dituntut mempelajari bahasa Arab sebagai salah satu bahasa internasional baik secara aktif maupun pasif, karena seiring dengan adanya persaingan di era globalisasi.

Bahasa Arab sudah menjadi mata pelajaran wajib di sekolah Madrasah Aliyah dan Pondok Pesantren (Departemen Pendidikan Agama, 2004). Departemen Pendidikan Agama (2004) menetapkan bahwa kemampuan yang harus dimiliki oleh siswa Madrasah Aliyah dan Pondok Pesantren adalah memahami dan mengungkapkan informasi, pikiran, serta mengembangkan ilmu pengetahuan, dan budaya dengan menggunakan bahasa Arab. Oleh sebab itu, agar dapat lulus, siswa harus memperoleh nilai yang sesuai dengan standar nilai bahasa Arab yang sudah ditetapkan. Harapannya, siswa Madrasah Aliyah dan Pondok Pesantren dapat serius dan semangat dalam belajar bahasa Arab, agar mampu dalam menguasai pelajaran bahasa Arab dengan baik dan berdampak pada nilai bahasa Arab yang baik juga.
Berdasarkan Kurikulum Tingkat Satuan Pendidikan (KTSP) tahun 2006 pada mata pelajaran bahasa Arab di SMA " $X$ " Yogyakarta, standar kompetensi mata pelajaran bahasa Arab adalah siswa dapat berkomunikasi dengan bahasa Arab yaitu mengamati, menanya, mengeksplorasi, mengasosiasi, mendengarkan, berbicara, membaca, dan menulis dengan menggunakan bahasa Arab. Kompetensi dasar yang harus dicapai oleh siswa dalam mata pelajaran bahasa Arab yaitu memahami cara penyampaian serta cara merespon, mengidentifikasi cara memberitahu dan menanyakan tentang fakta, perasaan, dan sikap terkait suatu topik, mendiskripsikan secara sederhana unsur kebahasaan, dan struktur teks. Mensimulasikan dialog sederhana tentang cara merespon ungkapan, mendemontrasikan ungkapan sederhana tentang cara memberitahu dan menanyakan fakta, perasaan, dan sikap, menyusun teks lisan dan tulisan sederhana untuk mengungkapkan terkait topik tertentu.

Jumlah siswa kelas XI di SMA " $X$ " Yogyakarta ada 245 orang yang terdiri dari dua kelas yaitu IPA dan IPS. Faktanya masih banyak siswa SMA " $X$ " Yogyakarta yang ditemukan membolos pada saat jam pelajaran bahasa Arab, tidak mengerjakan tugas, tidak mengumpulkan tugas tepat waktu, siswa malas 
belajar, merasa bosan dan jenuh dengan tugas bahasa Arab ataupun ketika belajar di kelas. Perilaku ini merupakan ciri-ciri rendahnya motivasi belajar siswa pada mata pelajaran bahasa Arab. Pada SMA "X" Yogyakarta ditemukan permasalahan yang sama. Hal ini ditunjukkan dengan data berikut ini, observasi yang dilakukan pada tanggal 18 sampai 22 Agustus 2015 di SMA " $X$ " Yogyakarta kelas XI, ada sekitar $25 \%$ siswa yang meninggalkan jam pelajaran bahasa Arab tanpa izin guru dan tidak kembali hingga jam pelajaran selesai. Siswa tidak mengerjakan tugas bahasa Arab. Ketika sedang di kelas, siswa sering bercanda dengan teman sebangkunya, sehingga tidak mengumpulkan tugas yang diberikan oleh guru. Pada saat pelajaran bahasa Arab, ada $25 \%$ siswa yang tidak mengerjakan dan mengumpulkan tugas yang diberikan oleh guru ketika di kelas. $30 \%$ siswa mencontek dalam mengerjakan tugasnya. Pada saat guru menjelaskan pelajaran di kelas, siswa terlihat bercanda dan mengobrol, dan mainan handphone sehingga suasana kelas terkesan gaduh pada saat pelajaran berlangsung.

Hasil wawancara dengan guru bahasa Arab, menunjukkan bahwa 50\% nilai ulangan masih di bawah standar KKM (Kriteria Ketuntasan Minimal) sehingga siswa harus mengikuti remidial untuk mencapai nilai 7,60 bahkan ada juga siswa yang mengikuti remidial lebih dari satu kali. Ada 20\% siswa sering keluar masuk kelas pada saat proses belajar berlangsung, dan 40\% siswa kurang memperhatikan jika diberikan penjelasan oleh guru. Ada 20\% siswa tidak menyelesaikan tugas yang diberikan oleh guru. Apabila diberi tugas masih ada $25 \%$ siswa yang tidak mengumpulkan tepat waktu. Nilai rata-rata ujian akhir sekolah bahasa Arab yaitu 6,80 yang masih berada di bawah standar KKM.

Hasil wawancara dengan guru Bimbingan dan Konseling juga menunjukkan hasil yang sama, yaitu siswa meninggalkan kelas pada saat proses belajar mengajar berlangsung, siswa tidak masuk sekolah, bahkan guru BK harus mengontrol kantin dan koperasi siswa agar mau mengikuti pelajaran dan masuk kelas. Hal ini dikarenakan kantin dan koperasi siswa dekat dengan kelas. Siswa pergi ke kantin karena tidak sempat sarapan pagi di rumah. Guru BK menyampaikan bahwa siswa lebih menyukai suasana yang penuh canda dan tidak terlalu serius ketika belajar di kelas sehingga mengakibatkan target materi pelajaran bahasa Arab tidak selesai. Guru BK sering mendapatkan laporan dari guru, ketika mata pelajaran bahasa Arab, 
siswa tidak mengerjakan tugas yang diberikan oleh guru di kelas, baik tugas di rumah maupun tugas di sekolah. Data yang diperoleh dari presensi kelas XI pada bulan Agustus 2015 tercatat ada 25 kasus siswa tidak masuk pada pelajaran bahasa Arab.

Selanjutnya, hasil wawancara dengan siswa SMA “X" Yogyakarta, menunjukkan bahwa ia sering tidak menyelesaikan tugas bahasa Arab yang diberikan oleh guru dan tidak mengumpulkan tugas rumah. Siswa tidak memiliki waktu belajar yang teratur, karena kegiatan di sekolah sampai sore dan malamnya ada les. Kemudian siswa mengaku sering tidak menyelesaikan tugas tepat waktu, bahkan sering mengumpulkan tugas di kelas tidak tepat waktu karena siswa sering mengobrol maupun bercanda dengan teman sebangkunya. Siswa juga mengaku jika menemui kesulitan dalam mengerjakan tugas bahasa Arab, tugasnya akan ditinggalkan begitu saja dan tidak diselesaikan. Siswa mengaku sering pergi meninggalkan proses belajar mengajar bahasa Arab untuk pergi ke kantin. Selain itu, pada saat ulangan, siswa juga mengaku sering mencontek, karena tidak belajar, sehingga tidak bisa menjawab soal yang diberikan oleh guru. Para siswa belum memiliki cita-cita yang ingin dicapai, belum memiliki tujuan yang spesifik dalam belajar bahasa Arab, belum memiliki metode yang tepat untuk belajar bahasa Arab agar mudah dipahami, dan tidak memiliki cara khusus dalam belajar bahasa Arab.

Perilaku ini pada umumnya merupakan ciri-ciri rendahnya motivasi belajar bahasa Arab. Menurut Suryabrata (2010), motivasi belajar merupakan keseluruhan daya penggerak psikis dalam diri siswa yang menimbulkan kegiatan belajar, menjamin kelangsungan belajar, demi mencapai suatu tujuan dengan menciptakan kondisi sedemikian rupa. Dengan permasalahan tersebut, maka tujuan penelitian ini untuk mengetahui pengaruh pelatihan goal setting terhadap peningkatan motivasi belajar bahasa Arab pada siswa kelas XI di SMA " $X$ " Yogyakarta.

Hasil penelitian ini diharapkan dapat memberikan sumbangan secara teoretis dalam memperkaya kajian ilmu psikologi terutama dalam bidang psikologi pendidikan bahwa dengan pelatihan goal setting mampu meningkatkan motivasi belajar bahasa Arab di SMA. Penelitian ini diharapkan menambah pengetahuan tentang teori motivasi belajar bahasa Arab pada siswa Sekolah Menengah Atas. Selain itu, peneliti ingin mengetahui apakah pelatihan goal setting dapat meningkatkan motivasi belajar 
bahasa Arab pada siswa kelas XI di SMA " $X$ " Yogyakarta, sehingga efek yang diharapkan dalam modul ini dapat dikembangkan lebih lanjut dengan format dan waktu yang lebih sesuai.

\section{METODE PENELITIAN}

\section{Desain Penelitian}

Penelitian ini merupakan penelitian eksperimen, dengan menggunakan variabel bebas berupa goal setting, variabel tergantung berupa motivasi belajar. Rancangan eksperimen yang digunakan adalah pre-post control group design. Pada desain ini, diawal penelitian ini dilakukan pengukuran terhadap variabel tergantung pada subjek. Kemudian setelah diberikan perlakuan dilakukan pengukuran kembali terhadap variabel tergantung pada subjek dengan alat ukur yang sama (Azwar, 2003). Rancangan eksperimen yang digunakan dalam penelitian ini adalah:

Tabel 1. Disain Penelitian

\begin{tabular}{lllll}
\hline Kelompok & Prates & Perlakuan & Pascates & Tindaklanjut \\
\hline KE & Y1 & $\mathrm{X}$ & $\mathrm{Y} 2$ & $\mathrm{Y} 3$ \\
$\mathrm{KK}$ & $\mathrm{Y} 1$ & - & $\mathrm{Y} 2$ & $\mathrm{Y} 3$ \\
\hline
\end{tabular}

\section{Subjek Penelitian}

Subjek penelitian ini adalah 26 siswa kelas XI SMA " $X$ " Yogyakarta. Pembagian subjek menggunakan teknik random assignment adalah prosedur memasukkan secara acak subjek pada sampel penelitian kedalam setiap kelompok penelitian (Azwar, 2003). Mata pelajaran yang digunakan dalam penelitian ini adalah bahasa Arab.

\section{Metode Pengambilan Data}

Langkah-langkah yang dilakukan oleh peneliti dalam melakukan pengumpulan data ini adalah: (1) Penyusunan skala motivasi belajar bahasa Arab, (2) Uji coba skala motivasi belajar bahasa Arab, (3) Wawancara, (4) Observasi.

Skala yang digunakan dalam penelitian ini adalah skala motivasi belajar yang dikembangkan oleh Putri (2011). Validitas skala ini adalah 0,219-0,586 dan reliabilitas skala ini adalah 0,996. Skala motivasi belajar bertujuan untuk mengukur motivasi belajar pada siswa SMA "X" Yogyakarta kelas XI. Skala ini mengacu pada teori McCown, Priscaol, dan Ropp (1996) yaitu (1) keinginan atau inisiatif sendiri untuk belajar; (2) keterlibatan secara sungguh-sungguh dalam 
proses belajar dan tugas yang diberikan; (3) komitmen untuk terus menerus belajar sehingga bertahan dalam pelajaran.

\section{Prosedur Penelitian dan Intervensi}

Prosedur pemberian perlakuan dalam penelitian ini dibagi menjadi beberapa tahap, yaitu: persiapan, pengukuran awal (pretest), pelaksanaan penelitian, pengukuran akhir (posttest), dan pelaksanaan tindakan (follow up).

Persiapan penelitian dilakukan dengan analisis kebutuhan, yaitu untuk mengetahui perlu atau tidaknya pelatihan diberikan pada siswa kelas XI di SMA " $X$ " Yogyakarta. Setelah analisis kebutuhan selesai, modul pelatihan disusun. Modul pelatihan goal setting disusun berdasarkan modul Anindita (2012) dengan memodifikasi beberapa konsep goal setting yang dikemukakan oleh Moran (Sukadji, 2010), dan Locke dan Latham (2006), yang memiliki komponen antara lain tujuan yang spesifik, terukur, realistik, memiliki batas waktu, menetapkan tujuan jangka panjang dan jangka pendek (SMART), clarity atau kejelasan, challenge atau tantangan, task complexity atau kompleksitas tugas, komitmen dan umpan balik.

Peneliti menjelaskan hak dan kewajiban fasilitator, ko-fasilitator, dan observer. Materi pelatihan yang diberikan fasilitator adalah modul pelatihan goal setting, sedangkan materi pelatihan yang diberikan kepada observer mencakup panduan observer. Pengukuran awal dilakukan dengan menggunakan skala motivasi belajar yang telah di uji coba dan dilihat validitas serta reliabilitasnya.

Tahap selanjutnya setelah tahap persiapan selesai dilaksanakan adalah pelaksanaan pelatihan, yaitu pelaksanaan pelatihan motivasi belajar bahasa Arab pada siswa kelas XI di SMA " $X$ " Yogyakarta. Pelatihan diberikan dalam tujuah sesi, yaitu pembukaan, inspirasi sukses, mengenal diri, penetapan tujuan, umpan balik, komitmen, dan penutup. Kelompok eksperimen diberikan pelatihan dengan durasi waktu 1,5 - 2,5 jam per sesi yang dibagi ke dalam dua kali pertemuan. Adapun kelompok kontrol mendapatkan intervensi setelah rangkaian penelitian selesai (wating list).

Pengukuran akhir dilakukan setelah pelatihan selesai dilaksanakan. Peserta diberikan lembar evaluasi pelatihan dan langsung dilakukan pascates dengan memberikan skala motivasi belajar bahasa Arab. Pelaksanaan tindak lanjut (follow up) dilaksanakan dua minggu setelah pelaksanaan posttest dilakukan. Pelaksanaan dilakukan dengan memberikan skala motivasi belajar bahasa Arab. Selain itu, dilakukan juga wawan- 
cara tentang sejauh mana pelatihan goal setting diterapkan dalam belajar.

\section{Teknik Analisis Data}

Analisis data yang digunakan dalam penelitian ini adalah analisis statistik. Metode yang digunakan untuk melihat motivasi belajar bahasa Arab pada siswa sebelum diberikan pelatihan goal setting dengan setelah diberikan pelatihan goal setting. Hasil analisis data dapat dilihat melalui analisis Uji Mann-Whitney. Analisis untuk menguji hipotesis dalam penelitian ini adalah dengan menggunakan gain skor Uji Mann-Whitney untuk mengetahui ada tidaknya pengaruh pelatihan goal setting untuk meningkatkan motivasi belajar bahasa Arab pada siswa kelas XI di SMA "X" Yogyakarta.

\section{HASIL PENELITIAN}

Analisis data dilakukan secara keseluruhan menggunakan analisis statistik uji Mann-Whitney. Priyatno (2012) mengatakan uji Mann-Whitney ini digunakan untuk menguji perbandingan dua rata-rata kelompok sampel yang independen. Analisis ini termasuk non parametrik sehingga tidak mensyaratkan data berdistribusi normal. Dari data pretest dan posttest skala motivasi belajar bahasa Arab diketahui nilai $Z=-4.359$ dengan $\mathrm{p}=0,000$ (nilai sig $<0,05$ ). Berarti, hipotesis diterima yaitu ada perbedaan motivasi belajar bahasa Arab sebelum pelatihan (pretest) dan setelah pelatihan goal setting (posttest). Kemudian motivasi belajar bahasa Arab dilihat lagi hasilnya dua minggu setelah pelatihan (follow up) diketahui nilai Z = 2.500 dengan $\mathrm{p}=0,012$ (nilai sig $<$ $0,05)$ yang berarti hipotesis diterima yaitu ada perbedaan motivasi belajar bahasa Arab sebelum pelatihan (pretest) dan dua minggu setelah pelatihan (follow up).

Berdasarkan data skor skala motivasi belajar bahasa Arab di atas, dapat diketahui motivasi belajar bahasa Arab berdasarkan skor yang diperoleh. Subjek termasuk dalam kategori motivasi belajar bahasa Arab rendah apabila memiliki skor kurang dari 57, subjek tergolong dalam kategori motivasi belajar bahasa Arab sedang jika mendapatkan skor berkisar antara 57-95, dan jika subjek termasuk dalam kategori memiliki motivasi belajar bahasa Arab yang tinggi apabila memiliki skor di atas 95. Dari 13 subjek pelatihan, semua subjek mengalami peningkatan setelah pelatihan (posttest). Dua minggu setelah pelatihan (follow up) mengalami penurunan, meskipun tidak sampai dalam kondisi semula, ada satu subjek yang mengalami penurunan seperti kondisi semula 
(pretest). Berdasarkan hasil wawancara dengan guru bahasa Arab setelah mengikuti pelatihan, intensitas membolos pada saat jam pelajaran bahasa Arab berkurang (sebelum intervensi $25 \%$ siswa membolos pada jam pelajaran, setelah dilakukan intervensi $10 \%$ siswa yang membolos), siswa mengerjakan tugas dan PR yang diberikan guru, dan siswa lebih memperhatikan ketika guru menjelaskan materi saat di kelas. Perbandingan skor tersebut dapat dilihat pada grafik di bawah ini:

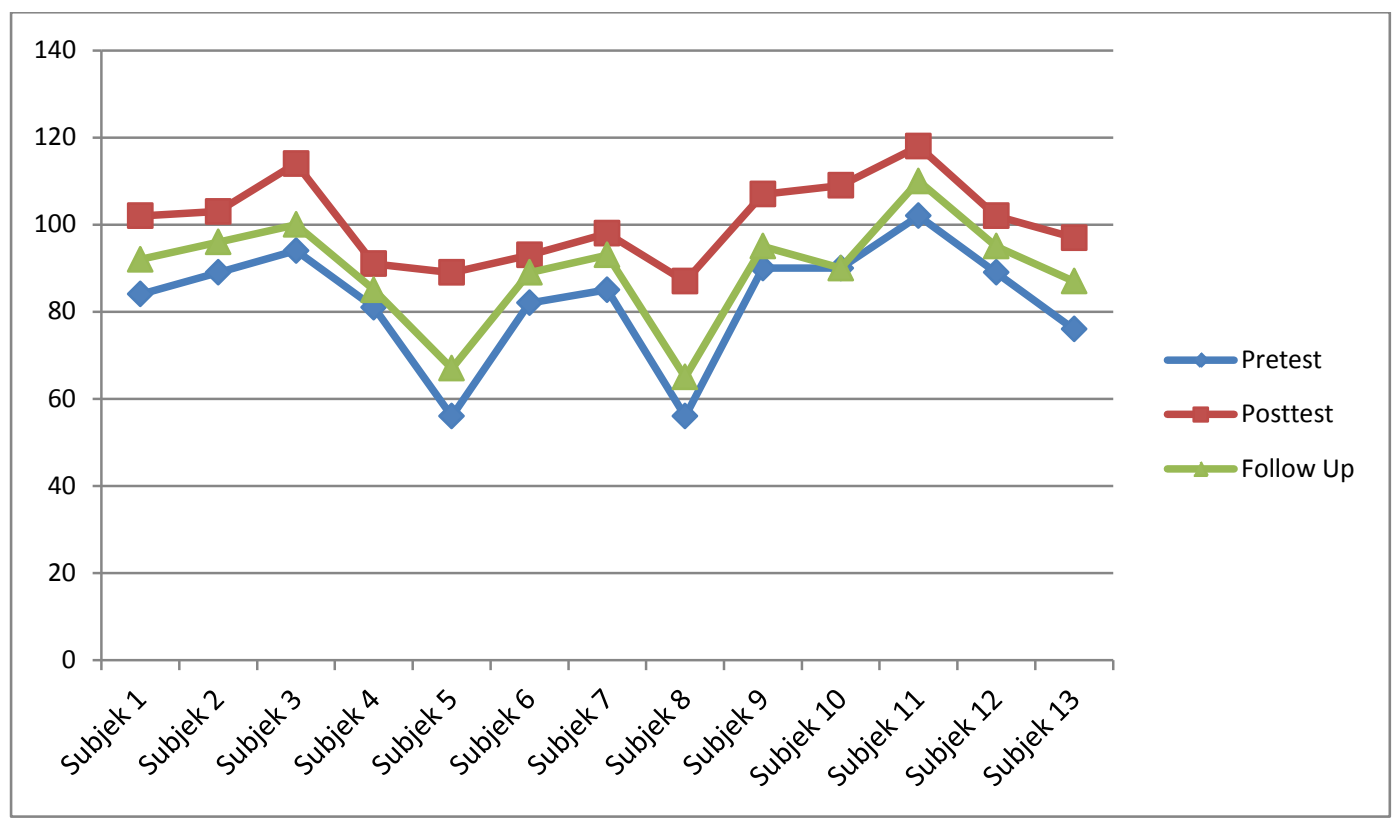

Grafik 1. Perbandingan skor skala motivasi belajar bahasa Arab siswa sebelum pelatihan, setelah pelatihan dan dua minggu setelah pelatihan

\section{PEMBAHASAN}

Penelitian ini bertujuan menguji efektivitas pelatihan goal setting dalam meningkatkan motivasi belajar bahasa Arab siswa. Hipotesis penelitiannya adalah ada perbedaan motivasi belajar antara sebelum dan sesudah pelatihan goal setting. Dari data prates dan pascates skala motivasi belajar bahasa Arab siswa diketahui nilai $Z=-4.359$ dengan $\mathrm{p}=0,000$ (nilai sig $<0,05$ ) berarti hipotesis diterima yaitu ada perbedaan motivasi belajar bahasa Arab sebelum pelatihan (pretest) dan setelah pelatihan goal setting (posttes). 
Kemudian motivasi belajar bahasa Arab dilihat lagi hasilnya dua minggu setelah pelatihan (follow up) diketahui nilai $Z=$ 2.500 dengan $p=0,012$ (nilai sig $<$ $0,05)$ yang berarti hipotesis diterima yaitu ada perbedaan motivasi belajar bahasa Arab sebelum pelatihan (pretest) dan dua minggu setelah pelatihan (follow up).

Diterimanya hipotesis yang diajukan dalam penelitian ini sesuai dengan penelitian yang dilakukan (Morisano, dkk. 2010) seseorang yang mempunyai tujuan yang jelas nampak lebih mampu untuk mengarahkan perhatian secara langsung, berusaha untuk melakukan aktivitas yang relevan dengan tujuan dan menjauhi usaha yang tidak relevan dengan pencapaian tugas, serta menampilkan kapasitas regulasi diri yang besar. Penetapan tujuan yang jelas juga akan menampakkan adanya peningkatan antusias, dan dengan adanya tujuan yang penting bagi seseorang akan mengantarkannya pada produksi energi yang besar dari pada tujuan yang tidak terlalu penting.

Locke dan Latham (dalam Sukadji, 2010) mengemukakan empat alasan mengapa goal setting dapat meningkatkan motivasi belajar dan memperbaiki performance, sebagai berikut: (1) goal mengarahkan perhatian seseorang terhadap tugas yang dihadapinya (goal untuk menyelesaikan tugas akan membuat individu untuk selalu mengarah perhatian kembali terhadap tugas tersebut); (2) goal menggerakkan usaha (semakin terasa sulit untuk mencapai goal, maka kecenderungan akan semakin besar usaha yang akan dilakukan); (3) goal meningkatkan ketahanan kerja (apabila seseorang memiliki goal yang jelas, maka kecenderungan akan lebih sedikit terganggu atau menyerah sebelum mencapainya). (4) Goal meningkatkan perkembangan strategi baru (apabila strategi yang telah dilakukan tidak berhasil, seseorang cenderung akan mencoba strategi lainnya untuk mencapai goal tersebut).

Menurut Elliot, dkk (2009) pada saat siswa sudah mempunyai tujuan maka, siswa mengetahui rintangan atau kendala dan strategi yang efisien untuk mencapai kesuksesan final. Pengalaman yang tidak menyebabkan stres karena memiliki sugesti positif untuk mencapai tujuan tersebut. Berusaha untuk mendapatkan tujuan yang menantang, strategi yang berbeda, melaksanakan tugas-tugas secara berkelanjutan.

Upaya pengenalan goal setting pada siswa dilakukan dengan pendekatan pelatihan. Pendekatan pelatihan dipilih karena pelatihan merupakan suatu metode pembelajaran yang bertujuan 
untuk mengubah aspek kognitif, afektif serta hasil keterampilan atau keahlian (Kikpatrick dalam Salas dkk, 2009). Johnson dan Johnson (2007) menyatakan bahwa metode pelatihan berdasarkan prinsip experiental learning, yaitu bahwa perilaku manusia terbentuk berdasarkan hasil pengalaman yang terlebih dahulu dimodifikasi untuk menambah efektivitas dan semakin lama perilaku menjadi suatu kebiasaan dan berjalan dengan otomatis serta individu semakin berusaha memodifikasi perilaku yang sesuai dengan situasi.

Pada pelatihan goal setting didasarkan pada prinsip pembelajaran experiental learning. Experiental learning terdapat lima tahapan, yaitu experiencing, publishing, processing, generalizing dan applying (Aryani \& Supriyanto, 2011). Pada pelatihan goal setting untuk meningkatkan motivasi belajar bahasa Arab siswa. Tahapan pertama experiencing yaitu dimana individu atau kelompok melakukan aktivitas. Pada pelatihan goal setting ini peserta melakukan beberapa simulasi permainan yang terkait dengan motivasi. Pada setiap permainan ada target perilaku yang diharapkan dicapai oleh peserta, yaitu memiliki tujuan yang spesifik dalam belajar bahasa Arab, mempunyai langkah-langkah atau strategi agar tujuannya dapat tercapai, memiliki batas waktu, kejelasan, tantangan, kompleksitas tugas, komitmen dan umpan balik.

Setelah melakukan permainan peserta melakukan diskusi dimana peserta sudah masuk pada tahapan publishing. Orang yang telah melakukan aktivitas akan membagikan pengalamannya, apa yang mereka rasakan selama melakukan aktivitas. Pada pelatihan ini peserta melakukan diskusi mengenai pelajaran apa saja yang dapat mereka ambil dari simulasi permainan yang sudah dilakukan. Misalnya pada permainan lempar bola, peserta menceritakan strategi untuk dapat memasukkan bola dalam keranjang, maupun memberikan masukan dan semangat kepada teman-temannya. Setelah itu, akan masuk pada tahapan processing dimana peserta saling memberikan masukan antar sesama peserta dari hasil diskusi sebelumnya. Akhirnya peserta menyadari bahwa mereka dapat melakukan perbaikan pada diri sendiri dan memiliki semangat untuk merubah diri.

Tahapan selanjutnya yaitu generalizing dimana peserta melihat pengalaman mereka, dan bagaimana hal itu dapat digunakan. Peserta pelatihan goal setting mengkaitkan simulasi permainan dengan kegiatan mereka ketika berada di sekolah, bagaimana belajar mereka di sekolah. Peserta mulai mengungkapkan 
perasaannya mengenai permasalahannya yang ada di sekolah. Semua peserta diberi kesempatan untuk berbicara dan saling memberi tanggapan dan masukan kepada peserta lain.

Tahapan yang terakhir adalah applying. Trainer membantu peserta menerapkan apa yang sudah digeneralisasi pada tahap sebelumnya ke dalam keadaan yang nyata. Pada tahap ini trainer mulai mengkerucutkan pendapatpendapat peserta dan membuatnya menjadi satu harapan kecil yang ingin dicapai bersama untuk memajukan sekolah. Di sini peserta mulai membuat komitmen pada diri mereka kemudian menuliskan dan membacakannya. Peserta melakukan komitmen dan perilaku mereka yang baru ketika berada di sekolah, sehingga setelah dua minggu pelatihan dilakukan pengukuran kembali.

Di sini peserta diberikan kesempatan untuk belajar membuat tujuan yang spesifik, measurable, action related, time based, clarity, challenge, task complexity, komitmen dan umpan balik. Dalam hal ini peserta dapat meningkatkan motivasi belajar bahasa Arab mereka karena peserta dapat belajar langsung dari simulasi-simulasi yang sudah dilakukan kemudian dikaitkan dengan kehidupan sehari-hari dan akhirnya peserta mendapatkan insight dari pemaknaan permainan. Hal ini juga sesuai dengan yang diungkapkan Ancok (2002) bahwa metode belajar dari pengalaman merupakan siklus belajar yang efektif, dimana ada pembentukan pengalaman, perenungan pengalaman, pembentukan konsep dan pengujian konsep.

Berangkat dari rendahnya motivasi belajar bahasa Arab, diperlukan adanya intervensi untuk memperbaiki motivasi belajar bahasa Arab siswa. Berdasarkan Kurikulum Tingkat Satuan Pendidikan (KTSP) tahun 2006 pada mata pelajaran bahasa Arab di SMA "X" Yogyakarta, standar kompetensi mata pelajaran bahasa Arab adalah siswa dapat berkomunikasi dengan bahasa Arab yaitu mengamati, menanya, mengeksplorasi, mengasosiasi, mendengarkan, berbicara, membaca, dan menulis dengan menggunakan bahasa Arab. Kompetensi dasar yang harus dicapai oleh siswa dalam mata pelajaran bahasa Arab yaitu memahami cara penyampaian serta cara merespon, mengidentifikasi cara memberitahu dan menanyakan tentang fakta, perasaan, dan sikap terkait suatu topik, mendiskripsikan secara sederhana unsur kebahasaan, dan struktur teks. Mensimulasikan dialog sederhana tentang cara merespon ungkapan, mendemontrasikan ungkapan sederhana tentang cara memberitahu dan 
menanyakan fakta, perasaan, dan sikap, menyusun teks lisan dan tulisan sederhana untuk mengungkapkan terkait topik tertentu.

Harapannya siswa SMA " $X$ " Yogyakarta dapat serius dan semangat dalam belajar bahasa Arab, tidak membolos, mengerjakan tugas dan PR yang diberikan oleh guru, memperhatikan penjelasan yang diberikan oleh guru, sehingga mampu memahami dan menguasai materi yang disampaikan guru di kelas dengan baik dan berdampak pada nilai bahasa Arab yang baik juga. Intervensi yang diberikan untuk meningkatkan motivasi belajar bahasa Arab adalah pelatihan goal setting. Setelah diberikan pelatihan goal setting, motivasi belajar bahasa Arab siswa meningkat hal ini ditunjukkan dari perilaku siswa antara lain intensitas membolos berkurang (sebelum intervensi $25 \%$ siswa membolos pada jam pelajaran, setelah dilakukan intervensi $10 \%$ siswa yang membolos), siswa mengerjakan tugas dan PR yang diberikan oleh guru, siswa lebih memperhatikan ketika guru menjelaskan materi).

Diterimanya hipotesis pada penelitian ini sesuai dengan penelitian-penelitian sebelumnya seperti yang dilakukan oleh Kaufman dan Husman (2010) bahwa persepsi murid tentang bagaimana mereka menetapkan tujuan belajar untuk masa depan secara positif berpengaruh terhadap motivasi belajar.

Penelitian yang dilakukan oleh Mansfield (2010) menyatakan bahwa pencapaian tujuan, tujuan sosial, tujuan masa depan siswa sangat mempengaruhi motivasi belajar. terutama terkait alasan masa depan untuk mencapai dan menunjukkan bahwa aspirasi masa depan yang akan dilakukan memang mempengaruhi motivasi belajar siswa. Selanjutnya, tujuan masa depan dikaitkan dengan kedua penguasaan dan tujuan kinerja.

Penelitian lain (Harackiewicz, dkk; 2009), menyebutkan bahwa goal setting belajar siswa mempengaruhi motivasi instrinsik siswa. Jika siswa memiliki goal setting belajar yang baik maka siswa memiliki motivasi belajar intrinsik yang tinggi juga, begitu sebaliknya jika siswa memiliki tujuan belajar yang rendah maka siswa memiliki motivasi intrinsik yang rendah.

Penelitian oleh Morisano, dkk (2010) pada 85 siswa yang mengalami kesulitan akademis, menunjukkan bahwa setelah diberikan intervensi goal setting, maka siswa menunjukkan perkembangan yang signifikan dalam peningkatan prestasi akademis dan motivasi belajar. Penelitian oleh Clarke, dkk (2009) menunjukkan bahwa pelatihan goal setting dapat meningkatkan usaha pencapaian 
tujuan dalam menyelesaikan pekerjaan atau tugas belajar. Penelitian oleh Haslam, dkk (2009), menunjukkan bahwa siswa yang mengikuti pelatihan goal setting lebih dapat mengaktualisasikan diri dan mengembangkan diri dalam mencapai tujuan belajar.

Permasalahan motivasi belajar bahasa Arab siswa sering muncul di sekolah. Hal ini dipengaruhi oleh faktor eksternal maupun faktor internal. Faktor eksternal antara lain, kondisi sekolah yang kurang mendukung baik sarana dan prasarana belajar bahasa Arab, metode guru mengajar, teman sebaya, dan pola asuh. Sedangkan faktor internal yaitu tujuan belajar, cita-cita, kemampuan siswa dan persepsi mengenai kemampuannya. Dalam penelitian ini subjek mengalami penurunan skor setelah dua minggu pelatihan, hal ini dapat dipengaruhi oleh faktor lain, seperti metode guru mengajar yang kurang tepat dengan kondisi siswa, maupun sarana dan prasarana sekolah.

\section{SIMPULAN DAN SARAN}

\section{Simpulan}

Berdasarkan analisis data dan pembahasan yang dilakukan maka dapat disimpulkan bahwa pelatihan goal setting dalam penelitian ini dapat meningkatkan motivasi belajar bahasa Arab pada siswa kelas XI SMA " $X$ " Yogyakarta. Hal ini dapat dilihat dari adanya peningkatan motivasi belajar siswa ketika di sekolah pada aspek keinginan atau inisiatif sendiri untuk belajar, keterlibatan secara sungguh-sungguh dalam proses belajar dan tugas yang diberikan, komitmen untuk terus belajar sehingga bertahan dalam pelajaran. Hal ini menunjukkan bahwa pelatihan goal setting memberikan pengaruh bagi perubahan motivasi belajar bahasa Arab pada siswa.

Berdasarkan analisis kualitatif didapatkan bahwa siswa mendapatkan beberapa manfaat selama melakukan pelatihan goal setting seperti memiliki cita-cita dan tujuan yang jelas untuk belajar bahasa Arab, dan membuat langkah-langkah yang harus dilakukan untuk mencapai tujuan, mendapatkan masukan atau umpan balik dari orang lain, saling memberikan dukungan dan semangat kepada teman.

\section{Saran}

Berdasarkan hasil penelitian, sekolah perlu melakukan screening siswa yang mengalami hambatan dalam motivasi belajar dengan menggunakan skala yang telah dilakukan oleh peneliti dan memberikan psikoedukasi dan konseling. Selain itu, konselor sekolah 
atau wali kelas juga dapat melakukan observasi di kelas maupun di lingkungan sekolah pada saat jam belajar sehingga siswa yang memiliki kebutuhan khusus dalam motivasi belajar mendapatkan penanganan. Guru dapat memotivasi siswa sebelum memulai pelajaran dengan modeling seperti menceritakan tokoh orang sukses, sehingga siswa diharapkan termotivasi untuk seperti orang tersebut dan akan belajar dengan sungguh-sungguh karena memiliki keinginan untuk sukses.

\section{DAFTAR PUSTAKA}

Ancok, D. (2002). Outbond Management Training. Yogyakarta: UII Press.

Anindita, D. (2012). Peningkatan prestasi belajar mata pelajaran bahasa indonesia pada siswa kelas xii IPA di SMA N "X" Lampung dengan menggunakan pelatihan goal setting. Tesis (tidak diterbitkan). Lampung: Universitas Negri Lampung.

Aryani, D \& Supriyanto, S. (2011). Peningkatan Efektivitas Tim Kerja Asuhan Keperawatan Melalui Metode Arung Alam. Jurnal Administrasi, Kebijakan, dan Kesehatan. 1 (3), 140-145.
Azwar, S. (2003). Metode penelitian. Yogyakarta: Pustaka Pelajar.

Clarke, S.P., Crowe, T.P., Oades, L.G., \& Deane, F.P. (2009). Do Goal Setting Intervention Improve The Quality Of Goal in Mental Healt Services. Psychiatric Rehabilitation Journal. 32 (4), 292-299.

Departemen Pendidikan Agama. (2004). Kurikulum Berbasis Kompetensi. Jakarta.

Elliot, A. J., Shell, M. M., Henry, K. B., \& Maier, M. A. (2009). Achievment Goal, Performance Contingencies, and Performance Attainment: An Experimental Tes. Journal of Educational Psychology, 97 (4), 630-640.

Harackiewicz, J.M., Sansone, C., \& Manderlink, G. (2009). Competence Achievment Orientation and Intrinsic Motivation: a Process Analysis. Journal of Personality and Social Psychology, 48 (2), 493-508.

Haslam, S.A., Wegge, J., \& Pastmes, T. (2009). Are we on a Learning Curve or a Treadmill? The Benefits of Participative Group Goal Setting Become Apparent as Task Become Increasingly Challenging Over Time. European Journal of Social Psychology. 39 (2), 430-446. 
Johnson, D. W \& Johnson, F. P. (2007). Joining Together: Group Theory and Group Skills. Boston: Allyn \& Bacon.

Kauffman, D.F., \& Husman, J. (2010). Effects of Time Perspective on Student Motivation: Introduction to a Special Issue. Educational Psychology Review, 16 (1), 1-7.

Locke, E. A \& Latham, G. P. (2006). A Theory of Goal Setting and Task Performance. Englewood Cliffs, NJ: Prentice Hall.

Mansfield, C. (2010). Motivating Adolescents: Goals for Australian Students in Secondary Schools. Australian Journal of Educational \& Developmental Psychology. 10 (3), 44-56.

McCown, R., Priscaol, M., Ropp, P. G. (1996). Educational Psychology: Learning Centerd Classical Approach Edition 2. MA: Simon and Schuster Companis.
Morisano, D., Hirs, J.B., Peterson, J., \& Shore, B.M. (2010). Setting Elaborating and Reflecting on Personal Goal Improves Academic Performance. Journal of Applied Psychology, 95 (2), 255-264.

Priyatno, D. (2012). Belajar Praktis Analisis Parametrik dan Non Parametrik dengan SPSS. Yogyakarta: Penerbit Gava Media.

Salas, E., Fowlkes, J.E., Stout, R.J., Milanovich, D.M., Prince, C. (2009). Does CRM Training Improve Teamwork Skills in the Cocpit?: Two Evaluation Studies. The Journal of The Human Factors and Ergonomics Society June 1999, 41 (2), 326-343.

Sukadji, S. (2010). Sukses di Perguruan Tinggi. Depok : Tidak Diterbitkan.

Suryabrata, S. (2010). Psikologi Pendidikan. Jakarta: Rajawali Press.

Syah, M. (2010). Psikologi Pendidikan. Bandung: PT Remaja Rosdakarya. 